\title{
Reproductive ecology and dispersal potential of varnish clam Nuttallia obscurata, a recent invader in the Northeast Pacific Ocean
}

\author{
Sarah E. Dudas ${ }^{1,3, *}$, John F. Dower ${ }^{1,2}$ \\ ${ }^{1}$ Department of Biology, and ${ }^{2}$ School of Earth \& Ocean Sciences, University of Victoria, PO Box 3020 STN CSC, Victoria, \\ British Columbia V8W 3N5, Canada \\ ${ }^{3}$ Present address: Department of Zoology, Oregon State University, 3029 Cordley Hall, Corvallis, Oregon 97331, USA
}

\begin{abstract}
The fecundity, larval development, and temperature and salinity tolerances were determined for the varnish clam Nuttallia obscurata (Reeve 1857), a recently introduced species in the Northeast Pacific. Adult varnish clams from 2 populations were collected in British Columbia, Canada throughout the spawning season to determine sex, fecundity, and timing of spawning. Adult varnish clams were also spawned in the laboratory and the larvae reared at a range of temperatures and salinities. The highest larval growth rates were observed in the $20^{\circ} \mathrm{C}$ and 20 psu treatments. Planktonic duration ranged from 3 to potentially $8 \mathrm{wk}$, with higher temperatures and salinities resulting in a shorter planktonic phase. Larvae reared at $9^{\circ} \mathrm{C}$, and at 10 and $15 \mathrm{psu}$, grew slowly and survived for a minimum of 1 mo but did not reach metamorphosis. These results indicate that varnish clam larvae have a wide range of salinity and temperature tolerances, but grow optimally at warmer temperatures and higher salinities. Varnish clams have comparable larval environmental tolerances and spawning duration to co-occurring bivalves. However, their fecundity appears to be slightly higher and they reach sexual maturity earlier, potentially providing an advantage in establishing new populations. The lengthy planktonic phase, combined with favourable oceanographic circulation patterns, has contributed to the rapid dispersal and geographic range expansion of the varnish clam in the Northeast Pacific.
\end{abstract}

KEY WORDS: Nuttallia obscurata · Invasion · Larval dispersal · Larval ecology · Environmental tolerance $\cdot$ Planktonic duration

\section{INTRODUCTION}

The varnish clam Nuttallia obscurata, an infaunal species originally native to Japan, Korea and China, was first reported in the Northeast Pacific in 1991 near Vancouver, British Columbia (BC) (Forsyth 1993), and was likely introduced via ballast water disposal in Vancouver Harbour (Gillespie et al. 1999). Its current geographical limits are Smith Sound $\left(51^{\circ} 17.07^{\prime} \mathrm{N}\right)$ in BC to the north (Gillespie \& Bourne 2004), and Coos Bay $\left(43^{\circ} 20.27^{\prime} N\right)$, Oregon, to the south. The varnish clam has proven extremely successful in $\mathrm{BC}$, expanding over $500 \mathrm{~km}$ and establishing known populations on over one hundred beaches, often attaining very high densities (eg. $800 \mathrm{~m}^{-2}$; Dudas 2005). Although the ecological impacts of this invasion are currently unknown, native predators are known to feed on the introduced species (Gillespie et al. 2001), possibly altering predator-prey interactions.

Life history characteristics often associated with successful invaders include short generation time, broad diet, and broad environmental tolerances (Ehrlich 1986). It is worth noting that these same characteristics may also be associated with 'unsuccessful' invaders. However, as the literature is likely biased toward reports of successful invasions, this is difficult to deter- 
mine. The characteristics that limit an invader may change over the course of the invasion, insofar as the characteristics that facilitate successful colonization (e.g. high fecundity, young size-at-maturity) may not be the same as those that facilitate dispersal and long term population maintenance (e.g. timing of spawning, lengthy planktonic phase, regular supply of immigrants; Vermeij 1996).

The invasibility of the recipient region will also influence the progression of an invasion. Factors suspected to increase invasibility include low species diversity (Stachowicz et al. 1999), disturbance (Hobbs \& Huenneke 1992) and human activities (Ruiz et al. 1997). The recipient region must also have a favourable climate and appropriate habitat (Swincer 1986). For marine invertebrates with a planktonic larval stage, the regional oceanography of the recipient region will be important, not only because of the 'climate' (i.e. temperature and salinity), but also because of mesoscale circulation patterns.

The varnish clam is a broadcast spawner (Miyawaki \& Sekiguchi 1999), with a peak spawning period occurring in the spring and sexual maturity occurring in just 1 yr (Hushan 1994). Laboratory studies in the Northwest Pacific indicate that the planktonic larvae can develop in temperatures of 15 to $25^{\circ} \mathrm{C}$ and can metamorphose in waters from 10 to $30^{\circ} \mathrm{C}$ (Hushan et al. 1997a). In BC, however, the varnish clam experiences cooler temperatures (i.e. 10 to $15^{\circ} \mathrm{C}$ ) and thus might be expected to have both slower growth and a longer planktonic phase. Understanding the salinity and temperature tolerance of larvae in this region will provide useful information regarding its potential for expanding its distribution in $\mathrm{BC}, \mathrm{a}$ region where there are many beaches with freshwater influence.

The present study examines the reproductive and early life history characteristics that may have contributed to the rapid spread of the varnish clam in coastal BC. The characteristics examined include: (1) adult sex ratios and fecundity, (2) timing of spawning, (3) larval development, (4) influence of temperature and salinity on larval growth and metamorphosis and (5) dispersal potential in the Northeast Pacific based on planktonic larval duration and regional oceanography. We also compare the varnish clam to co-occurring native and introduced bivalve species in order to highlight the life history characteristics that may have con- tributed to its success. Understanding the early life history of this species is essential for exploring its dispersal dynamics in the Northeast Pacific and how far (and to what extent) it will spread in the future.

\section{MATERIALS AND METHODS}

Sex ratio and timing of spawning. Adult varnish clams were collected from 2 beaches-Robbers Passage, in Barkley Sound on the west coast of Vancouver Island, and Bamberton Provincial Park (Bamberton, hereafter) in Saanich Inlet on the east coast of Vancouver Island, BC (Fig. 1). Collections were made on a monthly basis during the winter (approximately 12 clams per site), and weekly during spring and summer (approximately 12 to 25 clams per site) from May 2002 to January 2004. In the laboratory, dissections and gonad smears were conducted on clams spanning the dominant size ranges present at each site, in order to determine gonad presence and sex. Approximately 500 clams (1.5 to $6.0 \mathrm{~cm}$ shell length) were examined from Bamberton and 600 from Robbers Passage.

Timing of spawning was estimated by observing the percentage of clams with visible gonads (determined via smear technique above) at each site. Varnish clam 'egg puddles' were also observed at Robbers Passage around the periphery of siphon holes at low tide during

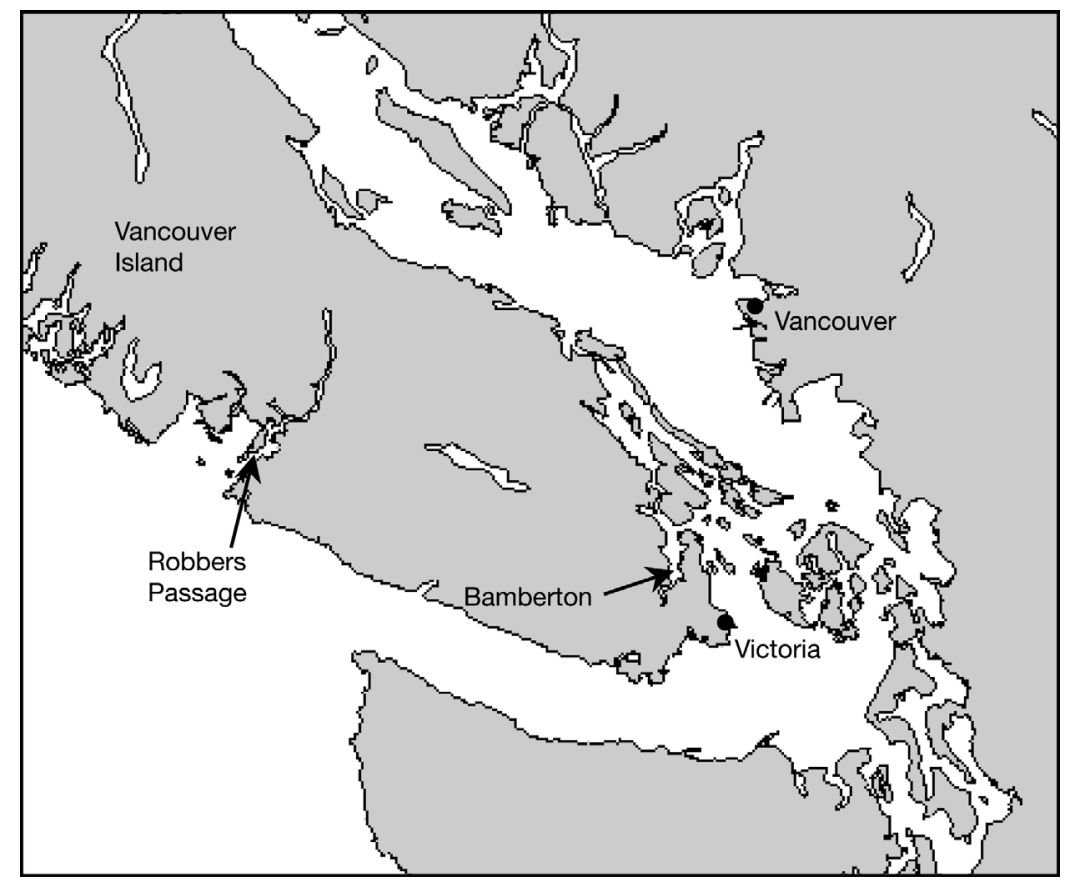

Fig. 1. Study region-Southern Vancouver Island, British Columbia (BC). Bamberton Provincial Park site located in Saanich Inlet, Robbers Passage site in Barkley Sound 
the spawning season. To confirm that the egg puddles were produced by varnish clams, the area around the siphon holes was excavated to establish that only varnish clams were buried beneath. Eggs were also taken back to the lab to determine whether they could be fertilized from stripped varnish clam sperm to further confirm species identity. Egg puddle observations were recorded on an approximately weekly basis during the reproductive season to better constrain estimates of peak spawning time at Robbers Passage. In 2002, seawater temperature and salinity were measured every $10 \mathrm{~min}$, at approximately $1 \mathrm{~m}$ depth, at Robbers Passage with an InterOceans S4 current meter deployed for the duration of the spawning season. Oceanographic conditions at Bamberton were approximated from temperature data collected hourly, by a permanent oceanographic buoy moored in Saanich Inlet, approximately $6 \mathrm{~km}$ away from the study site at $1 \mathrm{~m}$ depth, and provided by the Institute of Ocean Sciences in Sidney, BC.

Fecundity. Varnish clam gonad tissue was dissected from ripe females from both beaches (Robbers Passage $\mathrm{n}=63$, Bamberton $\mathrm{n}=57$ ) throughout the spawning season. Eggs were teased apart from the surrounding tissue to facilitate counting. Eggs were then suspended in seawater and several subsamples counted using a Sedgewick Rafter counting cell. This method for determining fecundity likely underestimates the number of eggs, and should therefore be considered a conservative estimate. Although the maturity of the eggs was not assessed and, therefore, egg counts actually represent 'potential fecundity', for the sake of simplicity the term 'fecundity' will be used hereafter. Adult shell length was measured following Harbo (1997). Clam size and fecundity relationships were compared between the 2 beaches using analysis of covariance (ANCOVA).

Flesh weights were also compared between sites (Robbers Passage $\mathrm{n}=104$, Bamberton $\mathrm{n}=97$ ). Clams for flesh weight comparisons were collected in January to minimize the influence of differences in gonad material. Flesh was excised from shells and was dried at $60^{\circ} \mathrm{C}$ until weight was constant. Clam size (i.e. shell length) and flesh weight relationships were compared between the 2 beaches with ANCOVA.

Larval development. Sexually mature adult varnish clams were collected from Robbers Passage and held in $12^{\circ} \mathrm{C}$ running seawater at the Bamfield Marine Sciences Centre (BMSC). All spawning trials and experiments were conducted using $0.45 \mu \mathrm{m}$ filtered seawater. To induce spawning, clams were placed in aquaria with $12^{\circ} \mathrm{C}$ seawater and fed a suspension of algal paste. After $2 \mathrm{~h}$ the water was replaced with $25^{\circ} \mathrm{C}$ seawater. Once spawning began, clams were moved to tanks with clean, filtered, $15^{\circ} \mathrm{C}$ seawater $(31 \mathrm{psu})$ to simulate typical conditions experienced during the spawning season. Egg and sperm sizes were recorded using an ocular micrometer. Approximately 1000 eggs and 10 sperm were measured to determine size. Upon evidence of fertilization, eggs were filtered gently onto a $20 \mu \mathrm{m}$ sieve and transferred to 21 culture vessels. Cultures were held at $15^{\circ} \mathrm{C}$, and developmental stage and embryo lengths (longest axis) were recorded approximately every $4 \mathrm{~h}$ until they reached the trochophore stage, after which measurements were taken twice a day until the first larval shell (prodissoconch I) had developed.

Temperature and salinity larval rearing experiments. Once the majority of larvae had developed into D-stage veligers (at approximately $48 \mathrm{~h}$ ), equal numbers of larvae were distributed into duplicate temperature treatments ( $\sim 500$ per replicate) at 9,15 and $20^{\circ} \mathrm{C}$ (held at an ambient salinity of 31 to $32 \mathrm{psu}$ ), and duplicate salinities of 10, 15 and 20 psu (held at an ambient temperature of $15^{\circ} \mathrm{C}$ ) in $1 \mathrm{l}$ culture vessels (i.e. $500 \mathrm{l}^{-1}$ ). This yielded a total of 12 cultures -2 for each temperature and 2 for each salinity level. Cultures were lightly aerated and water was changed 2 to 3 times a week. All cultures were maintained under an 18:6 h light:dark photoperiod cycle to simulate natural conditions. Larvae were fed a mix of cultured algae Isochrysis galbana and Pavlova lutheri at a rate of $4 \times 10^{4}$ cells $\mathrm{l}^{-1} \mathrm{~d}^{-1}$ (Strathmann 1987). In cases where bacterial contamination was observed, cultures were treated with a mixture of penicillin and streptomycin sulfate (Strathmann 1987), which has previously been shown to have no effect on the growth of varnish clam larvae (Hushan et al. 1997b). Larval shell length and height were measured twice weekly (using 15 individuals per culture) by extracting larvae from the culture, placing them in well slides in water from the culture, and then measuring them with an ocular micrometer mounted in a compound microscope. Larval shell length was defined as the longest axis of the shell parallel to the hinge. Height was defined as the longest axis of the shell perpendicular to the hinge. After measuring, larvae were returned to the cultures unless they had been damaged or killed during the measuring process. Larval shell lengths were averaged for each culture treatment and standard errors were calculated. Metamorphosis was defined as the point at which the larval velum had disappeared and only a foot remained, indicating preparation for the ontogenetic shift from planktonic to benthic existence. Larval period/planktonic duration was defined as the time from fertilization to metamorphosis. Experiments were continued until all larvae had either metamorphosed or died. Larval growth rates between treatments were compared using ANCOVA.

A separate experiment was conducted to determine whether laboratory growth rates were comparable to 
those observed in the field. Equal numbers of recently fertilized varnish clam eggs were split between a field-rearing chamber and a 21 larval rearing vessel held at $15^{\circ} \mathrm{C}$ and $31 \mathrm{psu}$ in the lab. The field-rearing chamber consisted of a capped section of PVC pipe (approximately 201 in volume) with 2 large windows covered in $53 \mu \mathrm{m}$ mesh which was anchored off the BMSC dock at approximately $1.5 \mathrm{~m}$ depth. A StowAway $^{\circledR}$ Tidbit data logger was attached to the fieldrearing chamber to monitor temperature during the experiment. Lab and field growth rates were compared using ANCOVA.

\section{RESULTS}

\section{Sex ratio and timing of spawning}

Sex ratios differed between the 2 populations. The female:male:hermaphrodite ratio in Robbers Passage was 0.46:0.49:0.05, while at Bamberton the ratio was 0.39:0.57:0.04, (with the high proportion of males at Bamberton deviating significantly from a 1:1 sex ratio, chi-square $=22.6, \mathrm{p}<0.0001$ ). The smallest female clam observed (across an overall size range of 1.4 to $6.8 \mathrm{~cm}$ ) was $2.3 \mathrm{~cm}$ in length, and the smallest male was $1.6 \mathrm{~cm}$.

All clams observed at both beaches possessed reproductive tissue (Fig. 2) from June to August 2003 and May to September 2002 (when only Robbers Passage was observed). In Robbers Passage, this coincided with seasonal increases in temperature in 2002. The first evidence of spawning occurred as temperature began to rise in June, and tapered off as temperature began to fall towards September (Fig. 3). Egg puddle observa-

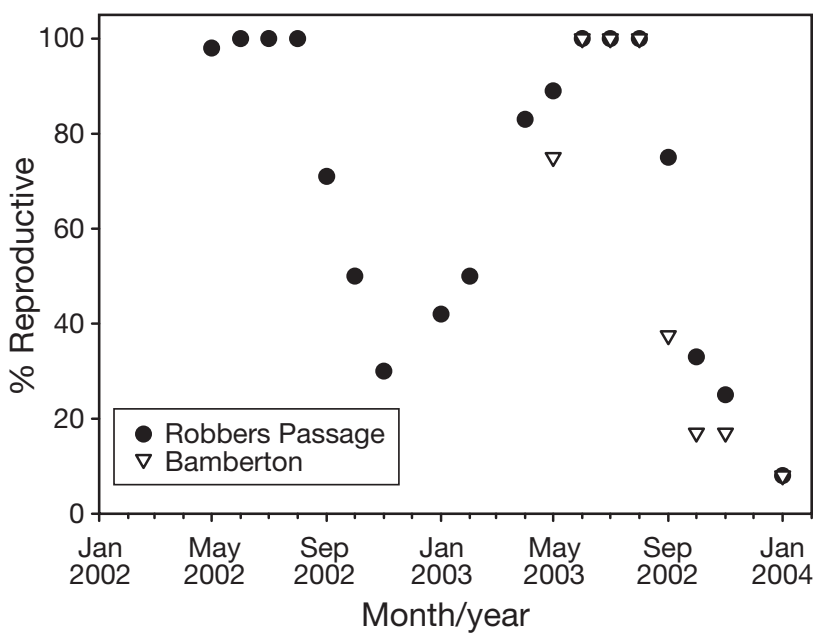

Fig. 2. Nuttallia obscurata. Percent of clams with gonads observed at Robbers Passage and Bamberton from May 2002 to Jan 2004 ( $\mathrm{n}=228$ per site)

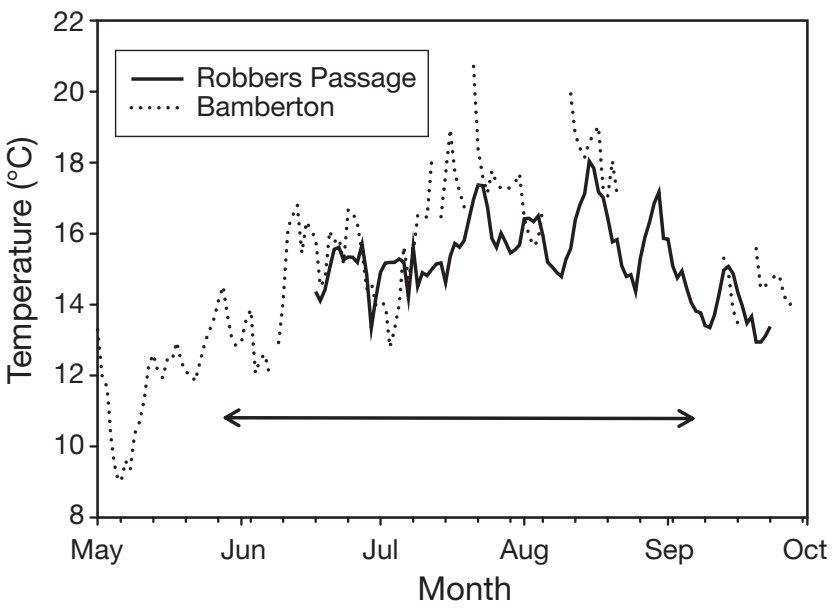

Fig. 3. Nuttallia obscurata. Time series of water temperatures $\left({ }^{\circ} \mathrm{C}\right)$ from Robbers Passage taken at $1 \mathrm{~m}$ depth, recorded every 10 min from June to Sept 2002, and Bamberton, taken at approximately $1 \mathrm{~m}$ depth, every hour from May to Sept 2002. Bar with arrows at bottom indicates spawning season in Robbers Passage

tions (Table 1) indicated that spawning events occurred between late May and the end of August in 2002. During 2003, evidence of spawning (i.e. presence of egg puddles) first appeared in early June and continued through early September. This suggests an extended spawning period that runs from June to September in Robbers Passage and from June to August at Bamberton.

Table 1. Nuttallia obscurata. Dates of varnish clam egg puddle observations from May 2002 to September 2003 for Robbers Passage (note that on some weeks egg puddles were observed but not counted). Observations made on an approximately weekly basis from last week of May to first week of September. Dates given as mm.dd.yy. Egg puddles were observed approximately $50 \%$ of the time

\begin{tabular}{|cc|}
\hline $\begin{array}{c}\text { Week } \\
\text { observed }\end{array}$ & $\begin{array}{c}\text { Approx. number } \\
\text { of egg puddles }\end{array}$ \\
\hline 05.27 .02 & 1 \\
06.03 .02 & $>20$ \\
06.10 .02 & \\
06.17 .02 & 8 \\
06.24 .02 & 5 \\
08.05 .02 & 2 \\
08.12 .02 & 1 \\
08.26 .02 & 30 \\
06.09 .03 & 7 \\
06.23 .03 & $>50$ \\
06.30 .03 & 12 \\
07.07 .03 & \\
08.04 .03 & \\
08.18 .03 & 2 \\
09.08 .03 & \\
\hline
\end{tabular}




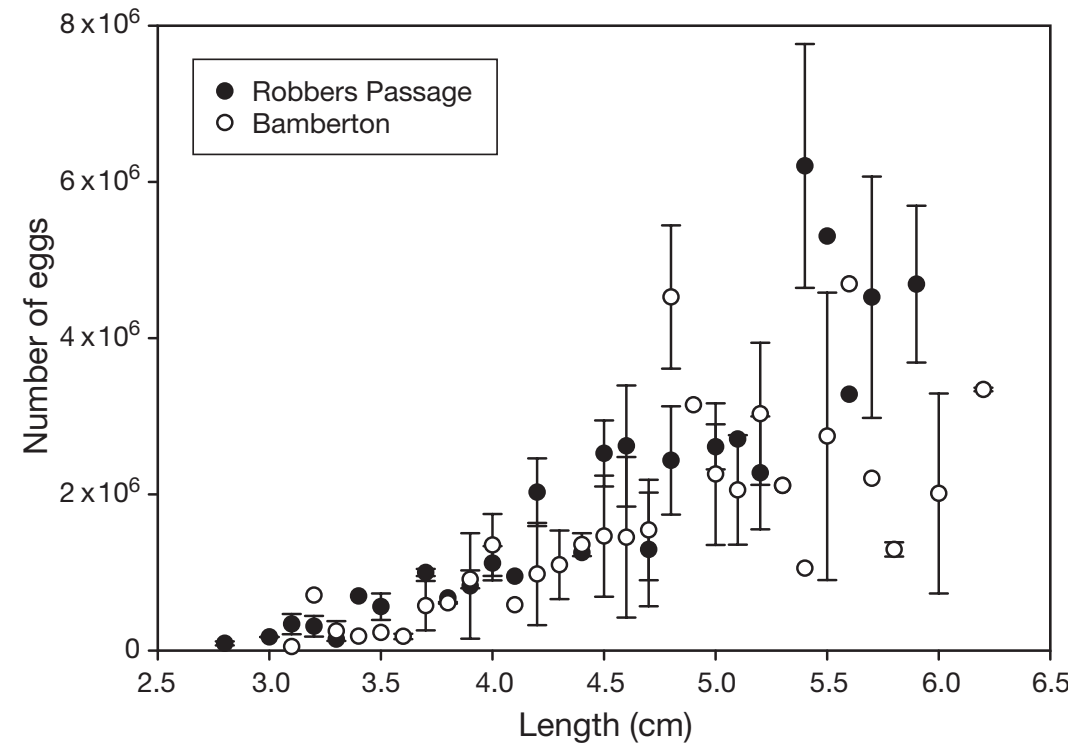

Fig. 4. Nuttallia obscurata. Shell length $(\mathrm{cm})$ vs. number of eggs for varnish clams collected in Robbers Passage $(n=63)$ and Bamberton $(n=57)$. Bars $=$ SE Data points without bars lacked sufficient data for error calculations

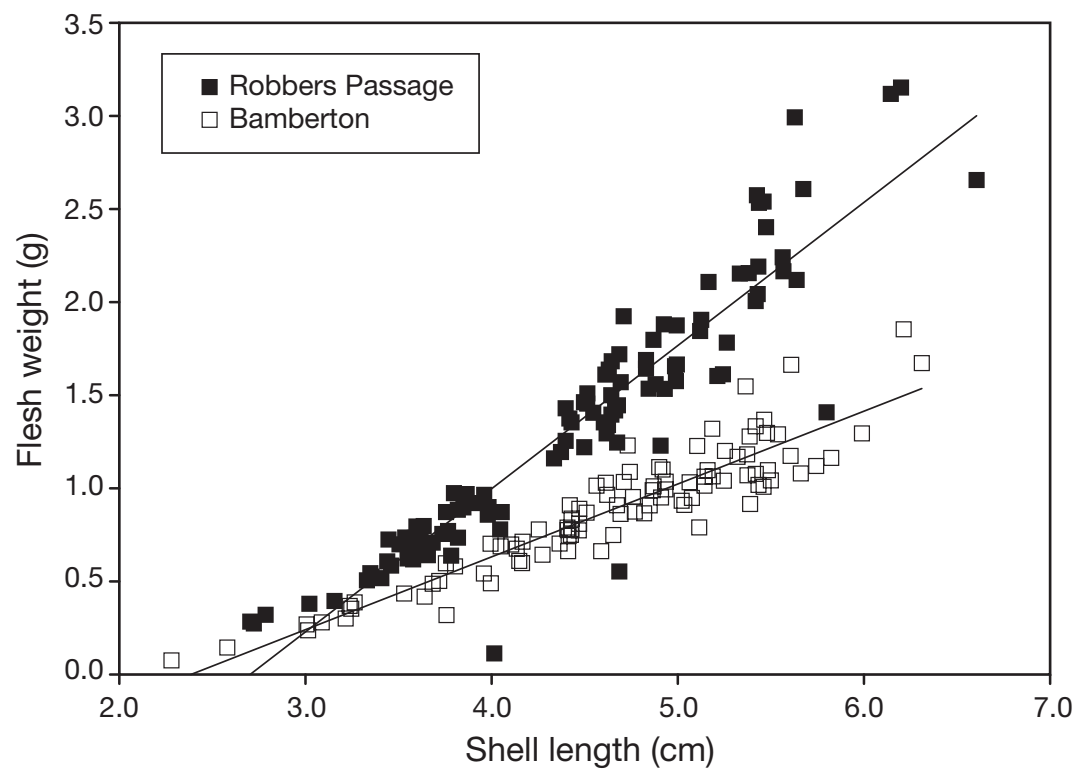

Fig. 5. Nuttallia obscurata. Shell length (cm) vs. flesh weight $(\mathrm{g})$ for varnish clams collected in Robbers Passage $(n=104)$ and Bamberton $(n=97)$. Lines are linear regressions

\section{Fecundity}

Clams of equivalent size contained approximately 1.5 times more eggs at Robbers Passage than at Bamberton ( $p<0.05, F=5.4$, df = 1,116, Fig. 4). Egg numbers ranged from $9 \times 10^{4}$ to $6 \times 10^{6}$ per female at Robbers Passage and $4 \times 10^{4}$ to $4 \times 10^{6}$ at Bamberton (likely conservative estimates). Egg numbers were highly variable, even among clams of the same length (e.g. $5 \mathrm{~cm}$ clam could have 2 to $3 \times 10^{6}$ eggs).

Flesh weight comparisons showed that Robbers Passage clams generally contained approximately twice as much flesh as Bamberton clams of the same size ( $p<0.05, F=58.3$, df = 1, 200, Fig. 5).

\section{Larval development}

Average oocyte diameter was approximately $55 \mu \mathrm{m}(\mathrm{n}=1000, \mathrm{SE}=1.21)$. Varnish clam sperm had an average length of $7.1 \mu \mathrm{m}(\mathrm{n}=10, \mathrm{SE}=1.0)$ not including the flagella (note, however, that this estimate is based on only 10 measurements). Sperm were released in a steady stream and were visible as a milky white fluid. Eggs were released in a similar manner but were less conspicuous. By $3 \mathrm{~h}$ postfertilization, eggs were at the 2 to 3 cell stage with unequal cleavages. By 6 h the blastomere had developed into a round ball of multiple cells (70 to $80 \mu \mathrm{m}$ ) and at $16 \mathrm{~h}$ the larvae had developed into freeswimming, acorn-shaped, trochophore larvae. By 43 h each larva had developed a straight-hinge, D-shaped shell (70 to $90 \mu \mathrm{m})$ and a ciliated velum, a stage typical of marine bivalve development and known as the 'D-stage' or straight-hinge veliger (named for the shape of the first larval shell, the prodissoconch I; Ackerman et al. 1994). Food was also evident in the larval gut by this stage.

\section{Temperature and salinity experiments}

When larvae were reared at $20^{\circ} \mathrm{C}$ the umbo first appeared on Day 12 (length = $170 \mu \mathrm{m})$, the larvae developed into pediveligers by Day 15, and settled out beginning on Day 19 (length = 180 to $200 \mu \mathrm{m})$. In the $9^{\circ} \mathrm{C}$ treatment larval development was extremely slow and only the presence of the umbo was observed by Day 36 (120 $\mu \mathrm{m}$; Table 2). Larvae in the $9^{\circ} \mathrm{C}$ treatment did not survive long enough to develop further.

At a temperature and salinity approaching ambient field conditions (i.e. $15^{\circ} \mathrm{C}, 31 \mathrm{psu}$ ), the umbo began to appear by Day 15 (shell length $=130 \mu \mathrm{m}$ ) signifying the beginning of the second larval shell, the prodissoconch 
Table 2. Nuttallia obscurata. Development timelines for varnish clam larvae in different larval rearing temperature $\left(9,15,20^{\circ} \mathrm{C}\right)$ and salinity (15 and $20 \mathrm{psu})$ treatments. Age = time (d) when at least 1 larva in culture subsample was observed at that stage. -: no development to stage

\begin{tabular}{|c|c|c|c|c|c|c|}
\hline \multirow[t]{2}{*}{ Treatment } & \multicolumn{2}{|c|}{ Veliger } & \multicolumn{2}{|c|}{ Pediveliger } & \multicolumn{2}{|c|}{ Juvenile } \\
\hline & $\begin{array}{l}\text { Size } \\
(\mu \mathrm{m})\end{array}$ & $\begin{array}{l}\text { Age } \\
\text { (d) }\end{array}$ & $\begin{array}{l}\text { Size } \\
(\mu \mathrm{m})\end{array}$ & $\begin{array}{l}\text { Age } \\
\text { (d) }\end{array}$ & $\begin{array}{l}\text { Size } \\
(\mu \mathrm{m})\end{array}$ & $\begin{array}{c}\text { Age } \\
\text { (d) }\end{array}$ \\
\hline \multicolumn{7}{|c|}{ Temperature $\left({ }^{\circ} \mathrm{C}\right)$} \\
\hline 9 & 120 & 36 & - & - & - & - \\
\hline 15 & 130 & 15 & 180 & 27 & 180 & 33 \\
\hline 20 & 170 & 12 & $170-180$ & 15 & $180-200$ & 19 \\
\hline \multicolumn{7}{|l|}{ Salinity } \\
\hline 15 & 150 & 30 & _ & _ & _- & - \\
\hline 20 & 160 & 20 & 180 & 27 & $180-210$ & 31 \\
\hline
\end{tabular}

\section{DISCUSSION}

The varnish clam population at Bamberton in Saanich Inlet had significantly more males than females, which is unusual for gonochoristic species in which the sex ratio is usually either close to 1:1 or skewed slightly towards females (Mackie 1984). Male-skewed sex ratios are generally uncommon, although they have been observed in some other dioecious bivalve species (Gaspar \& Monteiro 1999). Food levels, differential development rates, and different maximal lengths are all known to influence sex ratio (Sastry 1968, Marsden 1999, Baghurst \& Mitchell 2002).

II. At approximately $27 \mathrm{~d}$ (and an average pediveliger length of $180 \mu \mathrm{m}$ ) the foot became evident (Table 2). By Day 33 the larvae in this treatment were at $>180 \mu \mathrm{m}$ in length and possessed only a foot, completing metamorphosis.

In the salinity treatments, larvae reared at $10 \mathrm{psu}$ did not pass the D-stage veliger (even after $30 \mathrm{~d}$ in culture). Among larvae reared at $15 \mathrm{psu}$ the umbo appeared at Day $30(150 \mu \mathrm{m})$ but no larvae survived past this stage (Table 2). In the 20 psu treatment, larval development progressed at a rate similar to ambient ocean conditions (i.e. $15^{\circ} \mathrm{C}, 31 \mathrm{psu}$ ), with the umbo laid down at $20 \mathrm{~d}(160 \mu \mathrm{m})$, progression to the pediveliger by Day 27 (length $=180 \mu \mathrm{m})$, and metamorphosis at Day 31 (length = 180 to $210 \mu \mathrm{m}$ ).

Larval growth rates differed significantly among temperature treatments (ANCOVA, p $<0.0001, F=$ 583.1, $\mathrm{df}=3,1107)$. At 20 and $15^{\circ} \mathrm{C}$ the larval growth rates $\left(2.8\right.$ to 3.2 and 1.1 to $2.0 \mu \mathrm{m} \mathrm{d}^{-1}$ ) were 8 and 3 times higher than those observed at $9^{\circ} \mathrm{C}$ (Fig. 6A). The increase in growth rate corresponding to a $10^{\circ} \mathrm{C}$ increase in temperature (i.e. $Q_{10}$ ) was 4.9 , indicating strong temperature dependence. Larval growth rates also differed significantly among salinity treatments (ANCOVA, $p<0.0001, F=31.3$, df $=2,870$ ), with the highest growth rate observed at $20 \mathrm{psu}$ (1.3 to $1.5 \mu \mathrm{m}$ $\mathrm{d}^{-1}$ ), 5 times higher than 10 psu (Fig. 6B). Larval size at settlement was $\sim 180 \mu \mathrm{m}$, with settlement occurring as early as Day 19 (at $20^{\circ} \mathrm{C}$ ). The oldest larva observed with a velum was $59 \mathrm{~d}$ old (from the $15^{\circ} \mathrm{C}$ treatment), suggesting a planktonic duration of at least 3 , to potentially $8 \mathrm{wk}$.

Larval growth rates in the field and the lab were not significantly different over the first $11 \mathrm{~d}$ of culture (ANCOVA, $\mathrm{p}=0.176$ ) despite the fact that field temperatures varied considerably $\left(13\right.$ to $\left.22^{\circ} \mathrm{C}\right)$ while larvae in the lab were held at a constant $15^{\circ} \mathrm{C}$. After Day 11, temperatures in the field treatment decreased and the larvae experienced heavy mortality, leaving insufficient numbers to permit further comparison with lab cultures.
Increased frequencies of males typically occur at lower food levels and cooler temperatures (Lee et al. 2003). Temperature effects are an unlikely explanation for the differences observed here because Saanich Inlet typically has warmer temperatures than Barkley Sound. The presence of pinnotherid (pea) crabs in bivalves has also been associated with sex ratios skewed towards males (Christensen \& McDermott 1958). Interestingly, pea crabs were only observed in

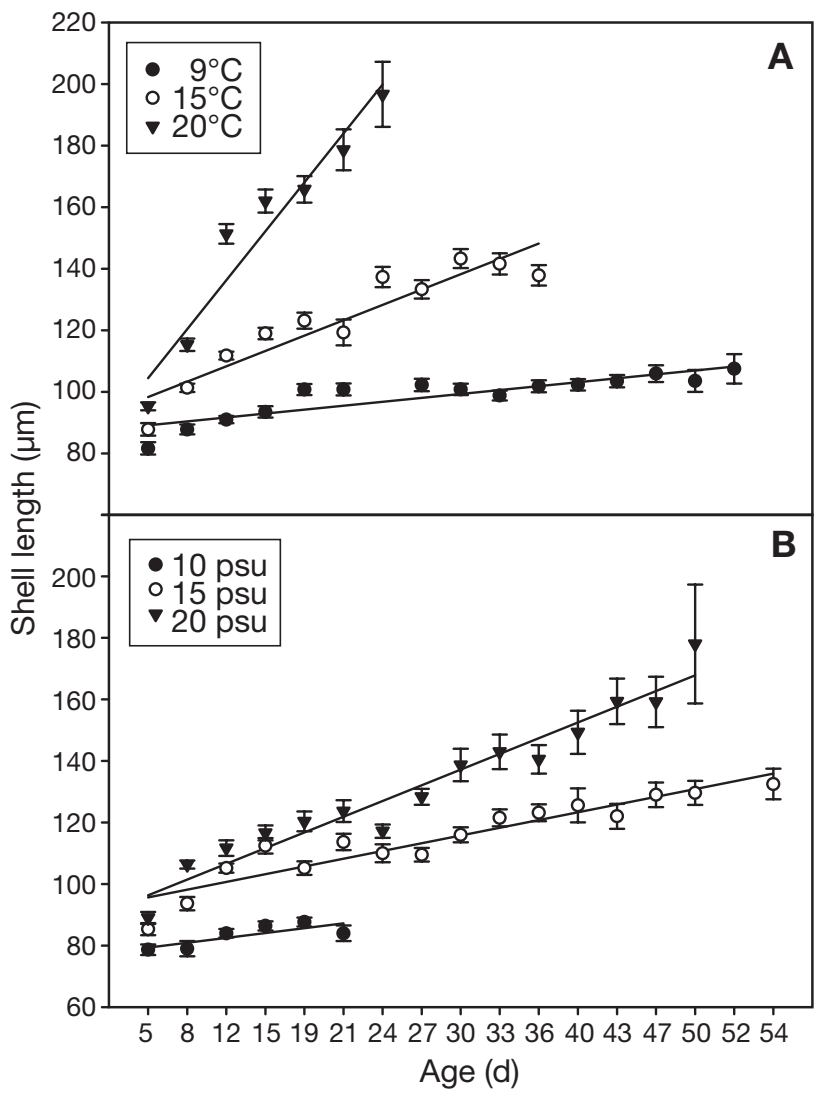

Fig. 6. Nuttallia obscurata. Larval age (d) vs. average shell length $(\mu \mathrm{m})$ for $(\mathrm{A})$ temperature $\left({ }^{\circ} \mathrm{C}\right)$ and $(\mathrm{B})$ salinity (psu) trials. Bars $=$ SE. Lines are linear regressions 
Bamberton clams and may have contributed to the higher abundance of males. Another varnish clam population, located about $100 \mathrm{~km}$ north of Bamberton, has also been found to have sex ratios skewed towards males and no evidence of hermaphrodites (L. Genn, unpubl. data). In Genn's study, males dominated the smaller size classes but the sex ratio leveled off to 1:1 in larger size classes, suggesting protandry. Whether the skewed sex ratio observed in varnish clam populations at these select sites is due to protandry, environmental differences, pea crab infestation, or a combination remains unclear.

The presence of functional hermaphrodites in varnish clam populations would be advantageous for an invasion. Hermaphrodites occurred in both populations at higher frequencies than those observed (usually $\sim 0.1 \%$ ) among other dioecious bivalves (Eversole 1986). However, it is unlikely that these individuals were functionally hermaphroditic, since the gonads did not appear to be regionally distinct or in separate zones (Mackie 1984). High frequencies of hermaphrodites and skewed sex ratios are often indicative of stressful environments (Eversole 1986), which may have contributed to the increase in hermaphrodites observed here due to the colder temperatures (i.e. relative to its native range) experienced by varnish clams in BC.

Small size-at-maturity enables varnish clams to reproduce quickly after settling, further increasing the chance of a successful invasion. The smallest varnish clams observed with eggs and sperm were 2.3 and $1.6 \mathrm{~cm}$, respectively. A more detailed reproductive study of varnish clams reported reproductive clams as small as $0.8 \mathrm{~cm}$ (L. Genn, unpubl. data). Assuming that 1.6 to $2.2 \mathrm{~cm}$ varnish clams are $1 \mathrm{yr}$ old (Choi 2001), this means that most of the varnish clams in the Bamberton and Robbers Passage populations reach maturity in their first year. This is quite young compared to co- occurring native bivalves that typically do not reach maturity until 2 to 3 yr (Table 3). Early maturation and high fecundity would provide further advantages to the varnish clam in the early stages of establishment (Bohn et al. 2004), and have likely contributed to its rapid increase in abundance. The fecundity of varnish clams is comparable to similar-sized local species at Robbers Passage and Bamberton (Table 3).

Similar to other bivalves in coastal BC (including native and introduced species), varnish clams spawn from late spring to early fall (Table 3 ). The spawning period begins just prior to the seasonal increase in temperature, indicating that larvae are developing in waters from approximately 13 to $16^{\circ} \mathrm{C}$. The consistent observation of egg puddles on the sand has not generally been documented for other bivalves in $\mathrm{BC}$, although it has been observed on rare occasions during mass spawnings of butter clams (Neil Bourne, pers. comm.). The eggs remain viable (S. E. Dudas unpubl. data) despite their exposure, allowing them to be fertilized on both outgoing and incoming tides, and may provide an advantage for increasing fertilization success.

The varnish clam exhibits a larval development pattern typical of marine bivalves (Quayle \& Bourne 1972, Sastry 1979, Ackerman et al. 1994). Its size at settlement is comparable to, or smaller than, other similar sized, soft-bottom bivalves with which it occurs (Table 4). Differences in larval rearing temperatures and salinities make it difficult to directly compare larval growth rates across species. However, there is no evidence that varnish clam larvae exhibit significantly faster growth than local bivalve species do (Table 4). Varnish clam larvae reared in a Japanese laboratory study grew faster (Hushan et al. 1997a) than the growth rates observed here (approximately $2 \mu \mathrm{m} \mathrm{d}^{-1}$ faster at $15^{\circ} \mathrm{C}$ and $1 \mu \mathrm{m} \mathrm{d}^{-1}$ at $20^{\circ} \mathrm{C}$ ). In addition to the co-occurring introduced bivalves

Table 3. Nuttallia obscurata. Egg size, fecundity, size/age-at-maturity and timing of spawning for the varnish clam and co-occurring bivalve species. Source = 1: Choi (2001), 2: L. Genn (unpubl. data), 3: Ponurovsky \& Yakovlev (1992), 4: DFO (1999a), 5: Quayle \& Bourne (1972), 6: Bourne (1982), 7: Loosanoff \& Davis (1963), 8: Brousseau \& Baglivo (1982), 9: Abraham \& Dillon (1986), 10: Goodwin \& Pease (1989), 11: DFO (2000), 12: DFO (1999b), 13: Strathmann (1987), 14: Bourne \& Smith (1972), 15: Harvey \& Vincent (1989), 16: Honkoop \& van der Meer (1997)

\begin{tabular}{|c|c|c|c|c|c|}
\hline Species & Egg size $(\mu \mathrm{m})$ & Fecundity (size) & Size/age-at-maturity & Timing of spawning & Source \\
\hline Nuttallia obscurata ${ }^{\mathrm{a}}$ & $46-55$ & $4 \times 10^{4}-6 \times 10^{6}(2.8-6.2 \mathrm{~cm})$ & $1.6 \mathrm{~cm} / 1 \mathrm{yr}$ & Late spring to early fall & 1,2 \\
\hline Venerupis philippinarum ${ }^{\mathrm{a}}$ & $60-75$ & $1.9 \times 10^{5}-2.4 \times 10^{6}(1.9-4 \mathrm{~cm})$ & $2-2.5 \mathrm{~cm} / 2-3 \mathrm{yr}$ & Late spring-summer & $3,4,5,6,7$ \\
\hline Mya arenaria ${ }^{\mathrm{a}}$ & $68-73$ & $2.4 \times 10^{4}(6 \mathrm{~cm})$ & $4-4.5 \mathrm{~cm} / 1-2 \mathrm{yr}$ & & 8,9 \\
\hline Panopea abrupta & & $7-10 \times 10^{6}$ & $4.5-7.5 \mathrm{~cm} / 3 \mathrm{yr}$ & June-July & 10,11 \\
\hline Saxidomus giganteus & & & $4 \mathrm{~cm} / 3-4 \mathrm{yr}$ & Late spring & 5 \\
\hline Protothaca staminea & & & $2.2-3.5 \mathrm{~cm} / 2-3 \mathrm{yr}$ & Late spring-summer & 5,12 \\
\hline Clinocardium nuttalli & 80 & & $2 \mathrm{yr}$ & Late spring & 5,13 \\
\hline Tresus capax & $60-70$ & & $7 \mathrm{~cm} / 3-4 \mathrm{yr}$ & Late Feb, early March & 5,14 \\
\hline Macoma balthica & $101-108$ & & $0.6-0.65 \mathrm{~cm} / 3 \mathrm{yr}$ & & 15,16 \\
\hline antroduced species & & & & & \\
\hline
\end{tabular}


Table 4. Nuttallia obscurata. Developmental timelines for a range of temperatures and salinities for the varnish clam and cooccurring bivalve species. Source = 1: Loosanoff \& Davis (1963), 2: Robinson \& Breese (1984), 3: Laing \& Utting (1994), 4: Strathmann (1987), 5: Abraham \& Dillon (1986), 6: Pekkarinen (1986), 7: Drent (2002), 8: Goodwin \& Pease (1989), 9: Goodwin (1973a,b), 10: Goodwin et al. (1979), 11: Quayle \& Bourne (1972), Shaw (1986), Chew \& Ma (1987), 12: Bourne \& Smith (1972), 13: Breese \& Phibbs (1970), 14: Bourne (1971)

\begin{tabular}{|c|c|c|c|c|c|c|c|c|}
\hline Species & $\begin{array}{l}\text { Temp. } \\
\left({ }^{\circ} \mathrm{C}\right)\end{array}$ & $\begin{array}{l}\text { Sal } \\
\text { (psu) }\end{array}$ & $\begin{array}{c}\text { Trochophore } \\
\text { length }(\mu \mathrm{m}) / \\
\text { time }(\mathrm{d} / \mathrm{h})\end{array}$ & $\begin{array}{c}\text { D-stage } \\
\text { length }(\mu \mathrm{m}) / \\
\text { time }(\mathrm{d})\end{array}$ & $\begin{array}{c}\text { Veliger } \\
\text { length }(\mu \mathrm{m}) / \\
\text { time }(\mathrm{d})\end{array}$ & $\begin{array}{c}\text { Pediveliger } \\
\text { length }(\mu \mathrm{m}) / \\
\text { time }(\mathrm{d})\end{array}$ & $\begin{array}{l}\text { Settlement } \\
\text { length }(\mu \mathrm{m}) / \\
\text { time }(d)\end{array}$ & Source \\
\hline Nuttallia obscurata ${ }^{\mathrm{a}}$ & $\begin{array}{r}15 \\
9 \\
15 \\
20 \\
15 \\
15 \\
15\end{array}$ & $\begin{array}{l}31 \\
31 \\
31 \\
31 \\
10 \\
15 \\
20\end{array}$ & $70-80 / 16 \mathrm{~h}$ & $70-90 / 43$ & $\begin{array}{c}120 / 36 \\
130 / 21 \\
170 / 12 \\
\text { None survived } \\
150 / 30 \\
160 / 20\end{array}$ & $\begin{array}{c}180 / 27 \\
170-180 / 17 \\
\\
180 / 27\end{array}$ & $\begin{array}{l}>180 / 33 \\
180-200 / 19 \\
\\
180-210 / 31\end{array}$ & \\
\hline $\begin{array}{l}\text { Venerupis } \\
\text { philippinarum }^{\mathrm{a}}\end{array}$ & $\begin{array}{c}20 \\
25 \\
14 \\
14 \\
19 \\
10 \\
10-30 \\
21 \\
13-16\end{array}$ & $\begin{array}{c}- \\
20-30 \\
20-25 \\
30 \\
20-30 \\
10-30 \\
10-15 \\
29-32\end{array}$ & $1 \mathrm{~d}$ & 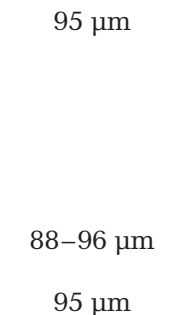 & $120-140 \mu \mathrm{m}$ & $\begin{array}{c}19-22 \\
200-220 / 15-17\end{array}$ & $\begin{array}{l}175-220 / 14 \\
165-180 / 19 \\
29 \\
\text { None survived } \\
\\
\text { None survived } \\
\text { None survived } \\
21-28\end{array}$ & $\begin{array}{l}1 \\
2 \\
2 \\
2 \\
2 \\
2 \\
2 \\
3 \\
4 \\
4\end{array}$ \\
\hline Mya arenaria ${ }^{\mathrm{a}}$ & $\begin{array}{c}20 \\
\text { Cold }\end{array}$ & & $12 \mathrm{~h}$ & $\begin{array}{l}86-90 \mu \mathrm{m} \\
24-36 \mathrm{~h}\end{array}$ & $\begin{array}{l}123-155 \mu \mathrm{m} \\
2-6 \mathrm{wk}\end{array}$ & $165 \mu \mathrm{m}$ & $\begin{array}{l}170-228 / 28 \\
28-42\end{array}$ & $\begin{array}{l}1 \\
5\end{array}$ \\
\hline Macoma balthica & $\begin{array}{r}4 \\
10 \\
15 \\
20\end{array}$ & & $2-3 d$ & $5 \mathrm{~d}$ & & & $\begin{array}{l}235-268 / 22-32 \\
240-272 / 17-25 \\
220-270 / 15-22\end{array}$ & $\begin{array}{l}6 \\
7 \\
7 \\
7\end{array}$ \\
\hline Panopea abrupta & $\begin{array}{l}16 \\
14 \\
14\end{array}$ & & $\begin{array}{c}80-100 /<24 \mathrm{~h} \\
60-80 / 12 \mathrm{~h}\end{array}$ & $\begin{array}{c}111 / 48 \\
110 / 48 \\
24 \mathrm{~h}\end{array}$ & $\begin{array}{c}120 / 6 \\
165-400 / 2-16 \\
14\end{array}$ & & $\begin{array}{l}400-1500 / 16-35 \\
381 / 47 \\
260-280 / 21\end{array}$ & $\begin{array}{c}8 \\
9 \\
10 \\
10 \\
11\end{array}$ \\
\hline Tresus capax & 13 & $28-29$ & $24 \mathrm{~h}$ & $75 / 48$ & $140-150 \mu \mathrm{m}$ & $200-210 \mu \mathrm{m}$ & $260-280 \mu \mathrm{m}$ & 12 \\
\hline Saxidomus giganteus & $\begin{array}{c}18 \\
15-20\end{array}$ & $\begin{array}{l}25-31 \\
20-29\end{array}$ & $24 \mathrm{~h}$ & $142 / 48$ & $224 / 16$ & & $\begin{array}{l}311 / 22-30 \\
230-250 / 20-25\end{array}$ & $\begin{array}{l}13 \\
14\end{array}$ \\
\hline $\begin{array}{l}\text { Clinocardium nuttallii } \\
\text { a Introduced species }\end{array}$ & 15 & & & $18 \mathrm{~h}$ & & & & 4 \\
\hline
\end{tabular}

listed in Tables 3 \& 4, other bivalve invaders in BC include Mytilus edulis, M. galloprovincialis, Musculista senhousia, Crassotrea gigas, C. virginica, Trapezium liratum and Teredo navalis (Levings et al. 2002). Many of the species share common larval characteristics with the varnish clam such as a long planktonic larval phase, and the ability to tolerate a range of environmental conditions (Morton 1974, Kristensen 1979, Quayle 1988).

Temperature had a stronger effect on the growth of varnish clam larvae than did salinity, similar to local bivalve larvae (Culliney et al. 1974). In their native range, varnish clam larvae will only develop at salinities of 24 to 31 psu (Hushan et al. 1988). In coastal BC, however, the larvae are able to develop at salinities as low as $20 \mathrm{psu}$, and at growth rates equivalent to those observed at ambient salinity (30 psu) at the same tem- perature. Overall, despite the fact that its temperature and salinity tolerances are no greater than those observed for native species (Table 4), the larvae are capable of tolerating a wide range of conditions and appear to have a slightly longer planktonic phase.

The lengthy larval planktonic duration of the varnish clam has implications for its dispersal in coastal BC. Fig. 7 shows the surface circulation patterns in the Northeast Pacific during the summer. Average summer current speeds in $\mathrm{BC}$ range from 10 to $50 \mathrm{~cm} \mathrm{~s}^{-1}$ (Thomson 1982). Thus, assuming that the larvae behave as passive particles (i.e. lacking any vertical migratory behaviour), even a $10 \mathrm{~cm} \mathrm{~s}^{-1}$ current would be sufficient to carry them $180 \mathrm{~km}$ in just $3 \mathrm{wk}$. Timing of spawning indicates that temperatures are approximately $15^{\circ} \mathrm{C}$ when the larvae are in the water column, corresponding to a planktonic larval duration of at 


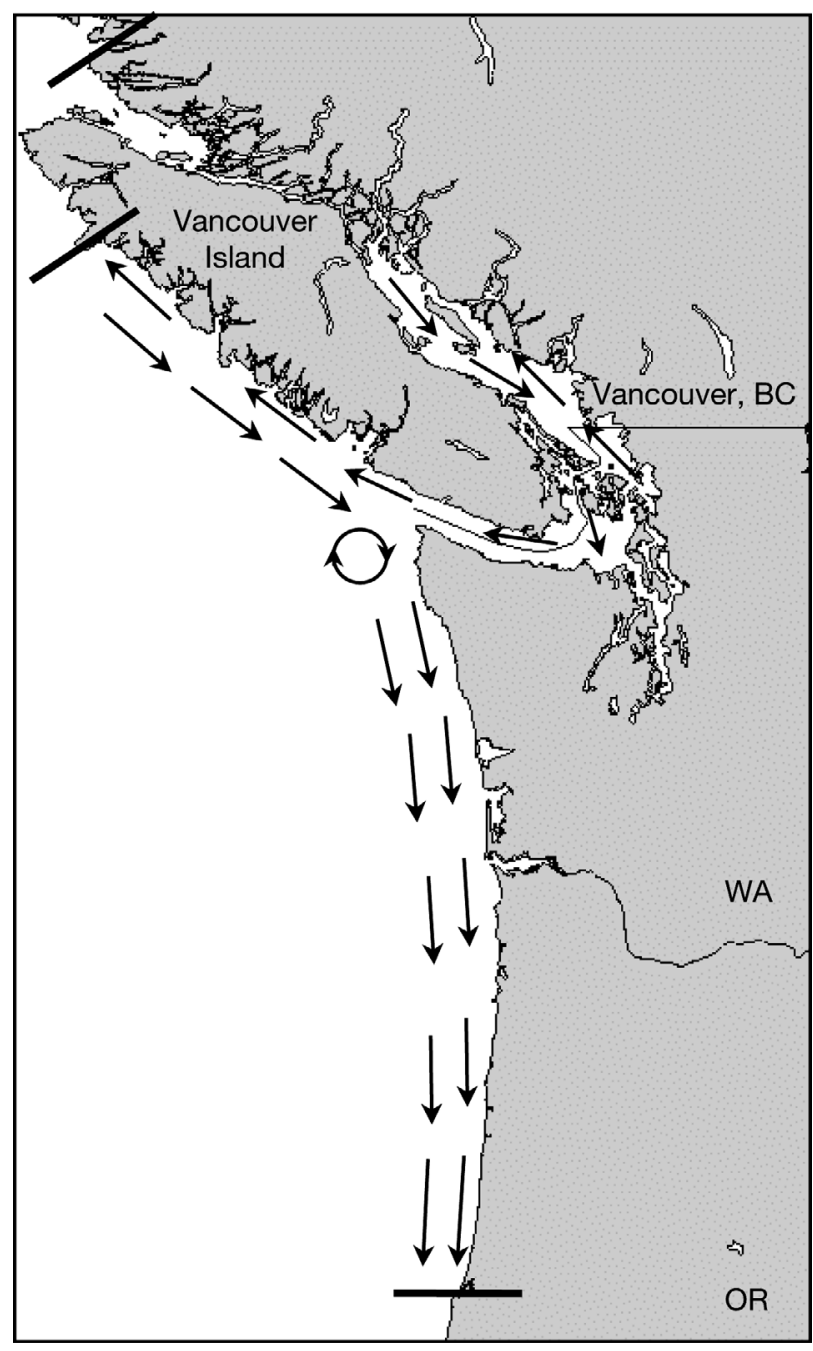

Fig. 7. Nuttallia obscurata. Generalized summer surface circulation patterns in northeast Pacific. Arrows = current direction. Circle $=$ Tully eddy off the mouth of Juan de Fuca. Bars = current varnish clam distributional limits. Based on data from Thomson (1982), Gillespie et al. (2001) and Gillespie \& Bourne (2004)

least 3 (and possibly up to 8) wk. Under such conditions, varnish clam larvae have the potential to disperse throughout their current geographic range in just one reproductive season. Given this dispersal potential, the fact that varnish clams are not found on all beaches with suitable habitat indicates that more localized oceanographic features may be influencing larval supply to beaches.

Assuming Vancouver Harbour to be the point of introduction (Gillespie et al. 1999), the varnish clam has already traveled approximately $500 \mathrm{~km}$ to reach its current northern limit on the west coast of Vancouver Island and $900 \mathrm{~km}$ to its southernmost population in Oregon. The physical oceanography in this region during the spawning period likely facilitated the invasion, by dispersing the larvae throughout regions where suitable habitat is abundant (i.e. the Strait of Georgia).

These oceanographic circulation patterns have played a role in past exotic species introductions as well. The Manila clam Venerupis philippinarum, a native of Japan, followed a similar invasion route in the 1930s (Bourne 1982), highlighting the importance of Vancouver Harbour as a hotspot for the introduction of nonindigenous species into the Strait of Georgia and nearby regions such as Puget Sound. The port of Vancouver is particularly susceptible to introductions due to its location in relation to oceanographic currents, and the fact that it is one of the endpoints for shipping traffic entering the Strait of Juan de Fuca (one of the busiest shipping corridors in North America). When invertebrate species with extended planktonic larval stages are introduced into this area they are likely to be rapidly dispersed not only throughout $\mathrm{BC}$ but also southwards towards Washington and Oregon.

The main steps in any invasion are the initial introduction and successful establishment of the species, followed by the expansion of populations in the new region (Vermeij 1996, Williamson \& Fitter 1996). For the varnish clam, small size-at-maturity likely contributed to its rapid establishment, allowing new settlers to reproduce within one year. Likewise, its high fecundity, lengthy planktonic phase and the favourable regional oceanographic circulation have also contributed to the rapid range expansion, dispersing larvae to the large number of suitable shellfish beaches in the Strait of Georgia. Other factors that may have contributed to its success include fast growth rate at small sizes, high survival rates, and its ability to occupy a niche previously devoid of other bivalves (i.e. high intertidal; Dudas 2005). The varnish clam invasion of the Northeast Pacific demonstrates how quickly an invader can establish and spread, when it possesses life history characteristics suited for both establishment and dispersal, particularly when these characteristics are supplemented with oceanographic circulation patterns that favour rapid dispersal throughout the recipient region.

Acknowledgements. This research was supported by an NSERC (National Sciences and Engineering Research Council of Canada) Postgraduate Scholarship A to S.E.D. and an NSERC Discovery Grant to J.F.D. We thank the Bamfield Marine Sciences Centre staff for providing research facilities and technical support, J. Gower at the Institute of Ocean Sciences for providing oceanographic data, S. Pond for assistance with the current meter, L. Gosselin for the use of his larval rearing chamber, T. Peters and G. White for assistance with larval rearing experiments and 3 anonymous reviewers for constructive comments. 


\section{LITERATURE CITED}

Abraham BJ, Dillon PL (1986) Species profiles: life histories and environmental requirements of coasts and fishes and invertebrates (mid-Atlantic) — softshell clam. US Fish Wildl Serv Biol Rep 82 (11.68)

Ackerman JD, Sim B, Nichols SJ, Claudi R (1994) A review of the early life history of zebra mussels (Dreissena polymorpha): comparisons with marine bivalves. Can J Zool 72:1169-1179

Baghurst BC, Mitchell JG (2002) Sex-specific growth and condition of the Pacific oyster (Crassostrea gigas Thunberg). Aquacult Res 33:1253-1263

Bohn T, Sandlund OT, Amundsen P, Primicerio R (2004) Rapidly changing life history during invasion. Oikos 106: 138-150

Bourne N (1971) The effects of temperature, salinity and food on the development of the larvae of butter clams, (Saxidomus giganteus, Deshayes). Proc Natl Shellfish Assoc 61:1 (Abstract)

Bourne N (1982) Distribution, reproduction, and growth of Manila Clam, Tapes philippinarum (Adams and Reeves), in British Columbia. J Shellfish Res 2:47-54

Bourne N, Smith DW (1972) The effect of temperature on the larval development of the horse clam, Tresus capax (Gould). Proc Natl Shellfish Assoc 62:35-38

Breese WP, Phibbs FD (1970) Some observations on the spawning and early development of the butter clam, Saxidomus giganteus (Deshayes). Proc Natl Shellfish Assoc 60:95-98

Brousseau DJ, Baglivo JA (1982) Estimation of equilibrium settlement rates for benthic marine invertebrates: its application to Mya arenaria (Mollusca: Pelecypoda). Fish Bull 80:642-644

Chew K, Ma AP (1987) Species profiles: life histories and environmental requirements of coasts and fishes and invertebrates (Pacific Northwest) - common littleneck clam. US Fish Wildl Serv Biol Rep 82 (11.78):22

Choi SH (2001) The study of secondary production of Nuttallia olivacea in the shore of Dadaepo, Pusan. MS thesis, National University, Pukyong, Korea

Christensen AM, McDermott JJ (1958) Life-history and biology of the oyster crab, Pinnotheres ostreum (Say). Biol Bull 114:146-179

Culliney JL, Boyle PJ, Turner RD (1974) New approaches and techniques for studying bivalve larvae. In: Smith WL, Chanley MH (eds) Culture of marine invertebrate animals. Plenum, New York, p 257-271

DFO (2000) Geoduck Clam. Report No. C6-03

DFO (1999a) Manila clam. DFO Science Stock Status Report C6-03

DFO (1999b) Native littleneck clam. DFO Science Stock Status Report. Report No. C6-02

Drent J (2002) Temperature responses in larvae of Macoma balthica from a northerly and southerly population of the European distribution range. J Exp Mar Biol Ecol 275: 117-129

Dudas SE (2005) Invasion dynamics of a non-indigneous bivalve, Nuttallia obscurata, (Reeve 1857), in the Northeast Pacific. PhD dissertation, University of Victoria, Victoria, BC

Ehrlich PR (1986) Which animal will invade? In: Drake JA (ed) Ecology of biological invasions of North America and Hawaii. Springer-Verlag, New York, p 79-95

Eversole AG (1986) Reproductive biology of clam populations in North America: a review. J Shellfish Res 7:117-118

Forsyth R (1993) Nuttallia obscurata, an introduced bivalve
(Psammobiidae) in British Columbia. Vancouver Shell News 14:9-12

Gaspar MB, Monteiro CC (1999) Gametogenesis and spawning in the subtidal white clam Spisula solida, in relation to temperature. J Mar Biol Assoc UK 79:753-755

Gillespie GE, Bourne NF (2004) Exploratory intertidal bivalve surveys. Can Man Rep Fish Aquat Sci 2734

Gillespie G, Parker M, Merilees B (1999) Distribution, abundance, biology and fisheries potential of the exotic varnish clam (Nuttallia obscurata) in British Columbia. Canadian Stock Assessment Secretariat Research Document 99/193: 39

Gillespie G, Rusch B, Gormican SJ, Marshall R, Munroe D (2001) Further investigations of the fisheries potential of the exotic varnish clam (Nuttallia obscurata) in British Columbia. Canadian Stock Assessment Secretariat Research Document 2001/143

Goodwin CL (1973a) Subtidal geoducks of Puget Sound, Washington. Wash Dep Fish Tech Rep 13

Goodwin CL (1973b) Effects of salinity and temperature on embryos of the geoduck clam (Panope generosa Gould). Proc Nat Shellf Assoc 63:93-95

Goodwin CL, Pease B (1989) Species profiles: life histories and environmental requirements of coasts and fishes and invertebrates (Pacific Northwest) - Pacific geoduck clam. US Fish Wildl Serv Biol Rep 82 (11.120):14

Goodwin L, Shaul W, Budd C (1979) Larval development of the Geoduck calm (Panope generosa, Gould). Proc Natl Shellfish Assoc 69:73-76

Harbo RM (1997) Shells and shellfish of the Pacific Northwest. Harbour Publishing, Madeira Park, BC

Harvey M, Vincent B (1989) Spatial and temporal variations of the reproduction cycle and energy allocation of the bivalve Macoma balthica (L.) on a tidal flat. J Exp Mar Biol Ecol 129:199-217

Hobbs RJ, Huenneke LF (1992) Disturbance, diversity and invasion: implications for conservation. Cons Biol 6:324-337

Honkoop PJC, van der Meer J (1997) Reproductive output of Macoma balthica populations in relation to winter-temperature and intertidal-height mediated changes of body mass. Mar Ecol Prog Ser 149:155-162

Hushan S (1994) On the sex gonad development and reproductive cycle of Nuttallia olivacea. Shangdong Fish 11: $13-16$

Hushan S, Gaojun X, Weigang W, Huanyu L (1988) Effects of salinity on embryonic development and growth of larvae of Nuttallia olivacea. Shangdong Fish 15:8-11

Hushan S, Wang W, Wang Y, Yu Z (1997a) The effects of temperature on embryonic development and growth of larvae of Nuttallia olivacea. Chin J Oceanol Limnol 2:54-58

Hushan S, Yiyan W, Wei H, Xiaowei D (1997b) The impact of 2 kinds antibiotics on the development of larval Nuttallia olivacea. Mar Fish 19:160-163

Kristensen ES (1979) Observations on growth and life cycle of the shipworm Teredo navalis L. (Bivalvia, Mollusca) in the Isefjord, Denmark. Ophelia 18:235-242

Laing I, Utting SD (1994) The physiology and biochemistry of diploid and triploid manila clam (Tapes philippinarum Adams \& Reeve) larvae and juveniles. J Exp Mar Biol Ecol 184:159-169

Lee H, Ban S, Ikeda T, Matsuishi T (2003) Effect of temperature on development, growth and reproduction in the marine copepod Pseudocalanus newmani at satiating food condition. J Plankton Res 25:261-271

Levings CD, Kieser D, Jamieson GS, Dudas S (2002) Marine and estuarine alien species in the Strait of Georgia, British Columbia. In: Claudi R, Nantel P, Muckle-Jeffs E (eds) 
Alien invaders in Canada's waters, wetlands and forests. Natural Resources Canada, Forest Service, Ottawa, p 19-28 Loosanoff VL, Davis HC (1963) Rearing of bivalve mollusks. Adv Mar Biol 1:1-136

Mackie GL (1984) Bivalves. In: Tompa AS (ed) The Mollusca: reproduction, Vol 7. Academic Press, New York, p 351-418

Marsden ID (1999) Reproductive cycles of the surf beach clam Paphies donacina (Spengler, 1793) from New Zealand. J Shellfish Res 18:539-546

Miyawaki D, Sekiguchi H (1999) Interannual variation of bivalve populations on temperate tidal flats. Fish Sci 65: $817-829$

Morton B (1974) Some aspects of the biology, population dynamics, and functional morphology of Musculista senhousia Benson (Bivalvia, Mytilidae). Pac Sci 28:19-33

Pekkarinen M (1986) Notes on the spawning, egg cleavage and early development of the bivalve Macoma balthica. Ann Zool Fenn 23:71-75

Ponurovsky SK, Yakovlev YM (1992) The reproductive biology of the Japanese littleneck, Tapes philippinarum, (A. Adams and Reeve, 1850) (Bivalvia: veneridae). J Shellfish Res 11:265-277

Quayle DB (1988) Pacific oyster culture in British Columbia. Can Bull Fish Aquat Sci 218:241

Quayle DB, Bourne N (1972) The clam fisheries of British Columbia. Report No. 179, Biological Station, Ottawa

Robinson AM, Breese WP (1984) Gonadal development and hatchery rearing techniques for the Manila clam Tapes philippinarum (Adams and Reeve). J Shellfish Res 4: 161-163

Editorial responsibility: Don Levitan (Contributing Editor), Tallahassee, Florida, USA
Ruiz GM, Carlton JT, Grosholz ED, Hines AH (1997) Global invasions of marine and estuarine habitats by nonindigenous species: mechanisms, extent, and consequences. Am Zool 37:621-632

Sastry AN (1968) Relationships among food, temperature and gonad development of the bay scallop, Aequipecten irradians Lamarck. Physiol Zool 41:44-53

Sastry AN (1979) Chapter 5-Pelecypoda (excluding Ostreidae). In: Pearse JS (ed) Reproduction of marine invertebrates, Vol V. Academic Press, New York, p 113-292

Shaw WN (1986) Species profiles: life histories and environmental requirements of coasts and fishes and invertebrates (Pacific Southwest) — common littleneck clam. US Fish Wildl Serv Biol Rep 82 (11.46)

Stachowicz JJ, Whitlach RB, Osman RW (1999) Species diversity and invasion resistance in a marine ecosystem. Science 286 1577-1579

Strathmann MF (1987) Reproduction and development of marine invertebrates of the Northern Pacific coast. University of Washington Press, Seattle, WA

Swincer DE (1986) Physical characteristics of sites in relation to invasions. In: Groves RH, Burdon JJ (eds) Ecology of biological invasions. Cambridge University Press, Cambridge, p 67-76

Thomson RE (1982) Oceanography of the British Columbia coast. Can Spec Publ Fish Aquat Sci 56:291

Vermeij GS (1996) An agenda for invasion biology. Biol Conserv 78:3-9

Williamson M, Fitter A (1996) The varying success of invaders. Ecology 77:1655-1661

Submitted: May 11, 2005; Accepted: February 2, 2006

Proofs received from author(s): August 4, 2006 